Research Paper

\title{
Human Apurinic/Apyrimidinic Endonuclease siRNA In- hibits the Angiogenesis Induced by X-Ray Irradiation in Lung Cancer Cells
}

Xianqing Gu1 ${ }^{1,2,}$, Yanping Cun ${ }^{1,}$, Mengxia Li ${ }^{1}$, Yi Qing 1 , Feng Jin ${ }^{1}$, Zhaoyang Zhong ${ }^{1}$, Nan Dai ${ }^{1}$, Chengyuan Qian', Jiangdong Sui ${ }^{1}$, Dong Wang1, ${ }^{1}$

1. Cancer Center, Daping Hospital and Research Institute of Surgery, Third Military Medical University, Chongqing 400042, China;

2. Department of Oncology, 285th Hospital of the Chinese People's Liberation Army, Handan 056001, China.

* These authors contributed equally to this work.

$\triangle$ Corresponding author: Tel.: +86 23 68757151; fax: +86 23 68894062. E-mail address:dongwang64@hotmail.com.

(1) Ivyspring International Publisher. This is an open-access article distributed under the terms of the Creative Commons License (http://creativecommons.org/ licenses/by-nc-nd/3.0/). Reproduction is permitted for personal, noncommercial use, provided that the article is in whole, unmodified, and properly cited.

Received: 2012.12.17; Accepted: 2013.05.08; Published: 2013.05.20

\begin{abstract}
Objective: Radiotherapy is an important and effective treatment method for non-small cell lung cancer (NSCLC). Nonetheless, radiotherapy can alter the expression of proangiogenic molecules and induce angiogenesis. Human apurinic/apyrimidinic endonuclease (APEI) is a multifunctional protein, which has DNA repair and redox function. Our previous studies indicated APEI is also a crucial angiogenic regulator. Thus, we investigated the effect of APEI on radiation-induced angiogenesis in lung cancer and its underlying mechanism.

Methods: Tumor specimens of I 36 patients with NSCLC were obtained from 2003 to 2008. The APEI and vascular endothelial growth factor (VEGF) expression, as well as microvessel density (MVD) were observed with immunohistochemistry in tumor samples. Human lung adenocarcinoma A549 cells were treated with Ad5/F35-APEI siRNA and/or irradiation, and then the cells were used for APEI analysis by Western blot and VEGF analysis by RT-PCR and ELISA. To elucidate the underline mechanism of APEI on VEGF expression, HIF-I a protein level was determined by Western blot, and the DNA binding activity of HIF-I $\alpha$ was detected by EMSA. Transwell migration assay and capillary-like structure assay were used to observe the migration and capillary-like structure formation ability of human umbilical veins endothelial cells (HUVECs) that were co-cultured with Ad5/F35-APEI siRNA and (or) irradiation treated A549 cells culture medium.

Results: The high expression rates of APEI and VEGF in NSCLC were $77.94 \%$ and $66.18 \%$, respectively. The expressions of APEI was significantly correlated with VEGF and MVD ( $r=0.369$, $r=0.387$ ). APEI and VEGF high expression were significantly associated with reduced disease free survival (DFS) time. The high expressions of APEI and VEGF on A549 cells were concurrently induced by X-ray irradiation in a dose-dependent manner. Silencing of APEI by Ad5/F35-APEI siRNA significantly decreased DNA binding activity of HIF-I $\alpha$ and suppressed the expression of VEGF in A549 cells, moreover, significantly inhibited the endothelial cells immigration and capillary-like structure formation induced by irradiated A549 cells.

Conclusion: Our results indicate that APEI may play a crucial role in angiogenesis induced by irradiation. Administration of Ad5/F35-APEI siRNA during radiotherapy could be a potent adjuvant therapeutic approach to enhance the radiotherapy response, effectively eliminate metastasis and improve the efficacy of radiotherapy for NSCLC.
\end{abstract}

Key words: Human apurinic/apyrimidinic endonuclease; angiogenesis; irradiation; lung cancer. 


\section{Introduction}

Lung cancer is the common malignant tumor and the leading cause of cancer death worldwide, comprising $12.7 \%$ of the total new cancer cases and $18.2 \%$ of the total cancer deaths[1]. Non-small cell lung cancer (NSCLC) accounts for more than $85 \%$ of all lung cancer cases. Radiotherapy is an important approach of local and regional therapy for many types of cancer and also is a highly effective treatment for NSCLC at the present $[2,3]$. Nonetheless, the outcome of radiotherapy alone is undesirable and many tumors are poorly controlled due to radiation resistance. Moreover, radiotherapy would potentially stimulate cancer invasion and metastasis[4, 5]. However, the mechanisms of radiotherapy induced tumor metastasis remain unknown. As we known, proangiogenic molecules are essential for radiation resistance, tumor progression and metastasis[6-12]. Proangiogenic molecules could play critical roles in radiation-induced tumor metastasis. Many studies have reported radiotherapy can stimulate multiple signal transduction pathways simultaneously and alter the expression of proangiogenic molecules including vascular endothelial growth factor (VEGF) in surviving cancer cells and host cells[13-17]. But the regulatory mechanism of VEGF overexpression in response to radiotherapy is still not clear.

The human apurinic/apyrimidinic endonuclease/redox factor-1 (hereafter, APE1) is a dual-function protein with both DNA repair and redox function. APE1 is an essential enzyme in the base excision repair (BER) pathway which is responsible for repair of abasic sites caused by oxidative and alkylation damage[18]. In addition to its DNA repair functions, APE1 also functions as a transcriptional coactivator, to reduce and activate transcription factors, including HIF-1a, AP-1, NF- $\mathrm{kB}$, which are crucial to the cellular response to oxidative stress[19]. Our previous studies and other reports have indicated that APE1 is a crucial proangiogenic regulator which modulates VEGF expression and angiogenesis through HIF-1a[20-22]. Also APE1 is showed high expression on the tumor tissues of many lung cancer patients, which is associated with response to chemotherapy or radiotherapy in NSCLC patients[23-25]. So it is reasonable to hypothesize that APE1 has the effect on radiation-induced angiogenesis in lung cancer through modulating VEGF expression.

In the present study, we first investigated the correlation between expression of APE1 and VEGF in NSCLC, and then further analyzed impact of APE1 on radiation-induced VEGF expression and consequent angiogenesis in vitro. We observed that increased ex- pression of the APE1 and VEGF on human lung adenocarcinoma A549 cells was concurrently induced by $X$-ray irradiation in a dose-dependent manner. Downregulation of APE1 significantly reduced DNA binding activity of HIF-1a and inhibited the expression of VEGF in A549 cells. More importantly, knockdown of APE1 significantly suppressed the endothelial cells immigration and capillary-like structure formation induced by X-ray irradiation in vitro. Our present study highlighted the effect of APE1 on angiogenesis induced by ionizing radiation, therefore inhibition of APE1 may be a promising approach to decrease angiogenesis and metastasis when combined with radiotherapy for NSCLC.

\section{Materials and Methods}

\section{Patients and Cell lines}

The present study involved 136 patients with NSCLC from 2003 to 2008 in the Daping Hospital of Third Military Medical University, China. All patients underwent radical surgery and the histological classification of the resected tumors was based on the World Health Organization criteria. The tumor stages were renewed according to the tumor/node/metastasis (TNM) classification developed by American Joint Committee on Cancer in 2010 [26]. No chemotherapy or radiotherapy was given to the patients before surgery. 102 patients were male and the median age was 59 years (range, 32 78 years). The stages range was from I to III. Patient characteristics are shown in Table 1. The control group was the normal lung tissues of 25 patients.

Human lung adenocarcinoma A549 cells and human umbilical veins endothelial cells (HUVECs) were purchased from American Type Culture Collection (Manassas, VA, USA). Both cell lines were grown in Dulbecco's modified Eagle's medium (DMEM) (HyClone, Logan, UT, USA) supplemented with 10\% fetal bovine serum, 100 units $/ \mathrm{ml}$ penicillin and $100 \mu \mathrm{g} / \mathrm{ml}$ streptomycin. Cells were grown at $37^{\circ} \mathrm{C}$ in a humidified incubator under $5 \% \mathrm{CO}_{2}$.

\section{Immunohistochemistry}

The expressions of APE1, VEGF and $\mathrm{CD}_{34}$ on the resected tumors were analyzed using immunohistochemistry[22, 23]. Sections from paraffin-embedded tumors were incubated $1 \mathrm{~h}$ with mouse anti-human APE1, VEGF and $\mathrm{CD}_{34}$ monoclonal antibody, and then incubated with goat anti-mouse secondary antibody. Antigen-antibody complexes were visualized by incubation with 3,3-diaminobenzidine (DAB) substrate and counterstained with diluted Harris hematoxylin. Tissues were scored for: (1) percentage of cell staining 
and (2) intensity of staining (weak, moderate, or strong). To be defined as low expression, the tissue needed to meet weak staining and positive cell percentage less than $50 \%$ or moderate staining and positive percentage less than $25 \%$. As high expression, the tissue needed to meet strong staining, or moderate staining and positive percentage more than $25 \%$ or weak staining and positive cell percentage more than $50 \%$. Microvessel was defined as any $\mathrm{CD}_{34}$-positive endothelial cells separate from adjacent microvessels. For the quantification of microvessel density (MVD), Counting at $\times 200$ magnification was performed by rotating the graticule to where the maximum number of stained vessels in the eye piece. 3 fields were captured for each section, and the results were expressed as the mean \pm standard deviation.

\section{Transfection assay}

Recombinant adenovirus vector Ad5/F35-APE1 siRNA and Ad5/F35-EGFP were constructed as described previously[27]. Transduction was carried out using Ad5/F35-EGFP or Ad5/F35-APE1 siRNA with 20 multiplicities of infection (MOI)[23]. Cells were infected for $90 \mathrm{~min}$ and were then washed to remove the adenoviruses. After transfection, cells were incubated for $48 \mathrm{~h}$ at $37^{\circ} \mathrm{C}$, and then used for the following assays.

HIF-1a siRNA (Invitrogen, Carlsbad, CA, USA) and the corresponding control oligonucleotides were purchased. HIF-1a-expressing vector was constructed by inserting HIF-1a cDNA into pcDNA3.1 vector. One day before transfection, cells were plated in growth medium without antibiotics. Cells were transfected with either HIF-1a siRNA or scramble siRNA and HIF-1a or control vector according to the manufacturer's instructions. After transfection, the cells were allowed to recover by incubating for $4 \mathrm{~h}$ at $37^{\circ} \mathrm{C}$, and then transferred into normal growth medium. Cells were cultured at $37^{\circ} \mathrm{C}$ in a $\mathrm{CO}_{2}$ incubator for the following assays.

\section{X-ray irradiation}

The cells were cultured in $25-\mathrm{cm}^{2}$ dish until they reached $70 \sim 80 \%$ confluence and then irradiated at room temperature with Elekta Precise Linear Accelerator operating at $8 \mathrm{MV}$, dose rate $200 \mathrm{cGy} / \mathrm{min}$, source to surface distance $100 \mathrm{~cm}$.

Table I. The relationship of clinicopathologic factors and APEI, VEGF protein expressions and MVD in NSCLC.

\begin{tabular}{|c|c|c|c|c|c|c|c|c|}
\hline \multirow{2}{*}{$\begin{array}{c}\text { Clinicopathologic } \\
\text { Data }\end{array}$} & \multicolumn{3}{|c|}{ APE1 expression } & \multicolumn{3}{|c|}{ VEGF expression } & \multirow{2}{*}{$\begin{array}{c}\text { MVD } \\
(\text { Mean } \pm S D)\end{array}$} & \multirow{2}{*}{ Pvalue } \\
\hline & Low & High & $P$ value & Low & High & Pvalue & & \\
\hline \multicolumn{9}{|l|}{ Sex } \\
\hline Male & 23 & 79 & \multirow{2}{*}{1.000} & 35 & 67 & \multirow[t]{2}{*}{1.000} & $30.32 \pm 6.58$ & \multirow{2}{*}{0.548} \\
\hline Female & 7 & 27 & & 11 & 23 & & $29.50 \pm 7.84$ & \\
\hline \multicolumn{9}{|l|}{ Age } \\
\hline$<60$ & 14 & 58 & \multirow{2}{*}{0.535} & 19 & 53 & \multirow[t]{2}{*}{0.069} & $30.49 \pm 6.91$ & \multirow{2}{*}{0.510} \\
\hline$\geq 60$ & 16 & 48 & & 27 & 37 & & $29.70 \pm 6.90$ & \\
\hline \multicolumn{9}{|l|}{ Histologic type } \\
\hline $\mathrm{Scc}$ & 7 & 42 & \multirow{3}{*}{0.181} & 15 & 49 & \multirow[t]{3}{*}{0.837} & $30.45 \pm 7.17$ & \multirow{3}{*}{0.779} \\
\hline $\mathrm{Ad}$ & 19 & 57 & & 27 & 34 & & $30.09 \pm 6.86$ & \\
\hline $\mathrm{Mc}$ & 4 & 7 & & 4 & 7 & & $28.82 \pm 6.24$ & \\
\hline \multicolumn{9}{|c|}{ Differentiation grade } \\
\hline Well & 2 & 6 & \multirow{3}{*}{0.775} & 3 & 5 & \multirow[t]{3}{*}{0.974} & $27.25 \pm 5.95$ & \multirow{3}{*}{0.250} \\
\hline Moderate & 24 & 80 & & 35 & 69 & & $29.96 \pm 7.08$ & \\
\hline Poor & 4 & 20 & & 8 & 16 & & $31.75 \pm 6.17$ & \\
\hline \multicolumn{9}{|l|}{ Tumor size $(\mathrm{cm})$} \\
\hline$<5$ & 19 & 46 & \multirow{2}{*}{0.064} & 31 & 34 & \multirow[t]{2}{*}{0.002} & $27.08 \pm 6.54$ & \multirow{2}{*}{0.000} \\
\hline$\geq 5$ & 11 & 60 & & 15 & 56 & & $32.90 \pm 6.01$ & \\
\hline \multicolumn{9}{|c|}{ Lymphatic nodal status } \\
\hline $\mathrm{N}_{0}$ & 14 & 32 & \multirow{2}{*}{0.125} & 22 & 24 & \multirow[t]{2}{*}{0.021} & $27.22 \pm 7.08$ & \multirow{2}{*}{0.000} \\
\hline$N_{1 \sim 3}$ & 16 & 74 & & 24 & 66 & & $31.60 \pm 6.33$ & \\
\hline
\end{tabular}




\section{Western blot analysis}

A549 cells were washed with ice-cold phosphate-buffered saline (PBS). Ten million A549 cells were added with $100 \mu \mathrm{L}$ cell lysis solution precooled to $0^{\circ} \mathrm{C}$, left on ice for $30 \mathrm{~min}$, centrifuged at $12,000 \mathrm{rpm}$, and placed at room temperature for $10 \mathrm{~min}$. Supernatants were added with $2 \times$ sodium dodecyl sulfate (SDS) gel loading buffer and denatured at $100^{\circ} \mathrm{C}$ for 5 min. Then, SDS-polyacrylamide gel electrophoresis (separation gel concentration, 12\%) and polyvinylidene fluoride (PVDF) membrane transferring were conducted. Whole-cell extracts $(20 \mu \mathrm{g} / \mathrm{lane})$ were resolved in SDS-polyacrylamide gel. The PVDF membrane was blocked with $5 \%$ defatted milk and detected with monoclonal antibodies directed against HIF-1a (R \& D Systems, Minneapolis, MN, USA), APE1 (Novus Biological, Littleton, CO, USA) and $\beta$-actin (Sigma, St Louis, MO, USA). The membranes were then incubated with a horseradish peroxidase-conjugated secondary antibody (Pierce, Rockford, IL, USA). The membranes was reacted with chemiluminescent regents (Pierce) and exposed onto film (Kodak).

\section{Reverse transcriptase-polymerase chain reac- tion (RT-PCR)}

After treatment, the cells were washed with ice-cold PBS, and total RNA was extracted using Trizol (Invitrogen, CA, USA). Reverse transcription was performed with PrimeScript ${ }^{\circledR}$ II 1st Strand cDNA Synthesis Kit (TaKaRa, Dalian, China) at $30^{\circ} \mathrm{C}$ for 10 $\min , 42^{\circ} \mathrm{C}$ for $45 \mathrm{~min}$ and $95^{\circ} \mathrm{C}$ for $5 \mathrm{~min}$ according to the manufacturer's instructions. The resulting cDNA were stored in $-80^{\circ} \mathrm{C}$ until use. The sequences of PCR primers (Invitrogen, Shanghai, China) were as follows: 5'-GGAGTGTGTGCCCACCGAGGAGTCCA AC-3' (forward) and 5'-GGTTCCCGAAACCCTGA GGGAGGCT-3' (reverse) for VEGF; 5'-GACCACACCTTCTACAATGAG-3' (forward) and 5'-GCATACCCCTCGTAGATGGG-3' (reverse) for $\beta$-actin. $2 \mu \mathrm{l}$ of cDNA was amplified in a $20 \mu \mathrm{l}$ PCR reaction volume with GoTaq $^{\circledR}$ Flexi DNA polymerase (Promega, Madison, WI, USA). The samples were first denatured at $94^{\circ} \mathrm{C}$ for $2 \mathrm{~min}$, followed by $30 \mathrm{PCR}$ cycles, each with temperature variations as follows: $94^{\circ} \mathrm{C}$ for $45 \mathrm{~s}, 58^{\circ} \mathrm{C}$ for $30 \mathrm{~s}$ and $72^{\circ} \mathrm{C}$ for $30 \mathrm{~s}$. The last cycle was followed by an additional extension incubation of $10 \mathrm{~min}$ at $72^{\circ} \mathrm{C}$. Analysis of amplification was accomplished on $2 \%$ agrose gel containing 0.2 $\mathrm{mg} / \mathrm{ml}$ ethidium bromide and visualized under UV transilluminator. The densitometric analysis of PCR products was performed by computer software using a GS-800 Imaging Densitometer (Bio-Rad, Hercules,
CA, USA) and standardized to $\beta$-actin product.

\section{Enzyme linked immunosorbent assay (ELISA)}

The level of VEGF in the culture supernatant was measured by the human VEGF ELISA kit (Neobioscience, China) according to the manufacturer's instruction. In brief, $100 \mu$ l of the culture supernatant was added to each ELISA plate well pre-coated with anti-human VEGF polyclonal antibody. After $1.5 \mathrm{~h}$ incubation at $36^{\circ} \mathrm{C}$, the plate was washed and then 100 $\mu \mathrm{l}$ of human VEGF conjugate was added to each well. The plate was incubated at $36^{\circ} \mathrm{C}$ for $1 \mathrm{~h}$. The plate was washed again and $100 \mu \mathrm{l}$ of substrate solution was added to each well. The plate was then incubated at $36^{\circ} \mathrm{C}$ in the dark for color development. After $30 \mathrm{~min}$, $100 \mu \mathrm{l}$ of stop solution was added to each well. Absorbance in each well was measured using microplate reader (Bio-Rad, Hercules, CA, USA) at $450 \mathrm{~nm}$. Concentration of VEGF in the culture supernatant was determined by interpolation from the standard curve and normalized by the numbers of tumor cells.

\section{Electrophoretic mobility shift assay (EMSA)}

Nuclear extracts were prepared from treated cells using the NE-PER Nuclear and Cytoplasmic Extraction Reagents (Thermo-Pierce, Rockford, USA). EMSA was accomplished using the LightShift ${ }^{\circledR}$ Chemiluminescent EMSA Kit (Thermo-Pierce, Rockford, USA) as previously detailed[28]. Briefly, 10 $\mu \mathrm{g}$ of nuclear proteins were incubated with biotin end-labeled and purified HIF-1a consensus double-stranded oligonucleotide. The DNA protein complexes were electrophoresed on 5\% native polyacrylamide gel using $0.5 \times \mathrm{TBE}$ buffer at $100 \mathrm{~V}$ for $1 \mathrm{~h}$, transferred to a nylon membrane at $380 \mathrm{~mA}$ for $0.5 \mathrm{~h}$, and detected using the Streptavidin-Horseradish Peroxidase Conjugate and the Chemiluminescent Substrate.

\section{Transwell migration assay}

The immigration of HUVECs was evaluated in Transwell cell culture chambers with a porous $(8.0 \mu \mathrm{m}$ pore size) polycarbonate terephthalates (PET) membrane filter (Millipore, USA). . Briefly, $2 \times 10^{5}$ HUVECs were seeded into the upper chamber. The lower chamber was filled with A549 culture medium that treated with irradiation, adenovirus vector Ad5/F35-APE1 siRNA, or combination of both. After $24 \mathrm{~h}$ of incubation, migrated cells were fixed and stained with hematoxylin and eosin (H\&E), and the number of migrated HUVECs was counted in five randomly selected fields under light microscopy (magnification, $\times 200$ ). 


\section{Capillary-like structure formation assay}

Capillary-like structure assay was carried out using human endothelial cell line HUVEC as previously described[29, 30]. In brief, $200 \mu \mathrm{l} /$ well of Matrigel $^{\mathrm{TM}}$ Matrix (BD Biosciences, USA) was added to each well of a 24-well plate and incubated for $30 \mathrm{~min}$ at $37^{\circ} \mathrm{C}$. The cells of treatment groups suspended in serum-free conditioned medium obtained from A549 cells culture supernatant that treated with irradiation, adenovirus vector Ad5/F35-APE1 siRNA, or combination of both. Control group had serum-free conditioned medium obtained from A549 cells culture supernatant without any treatment. HUVECs $\left(1 \times 10^{5}\right)$ were suspended in $600 \mu \mathrm{l}$ of conditioned medium, plated onto the gel matrix and incubated for $24 \mathrm{~h}$ at $37^{\circ} \mathrm{C}$. The capillary-like structures formed by HUVECs were photographed using a phase contrast inverted microscope (magnification, $\times 100$ ). Three independent experiments were performed.

\section{Statistical analysis}

Quantitative data were obtained from at least three independent experiments and expressed as mean \pm SD. Statistical analysis was performed using computer SPSS software SPSS 18.0 (SPSS, Chicago, IL, USA). The correlation between APE1 expression and clinico-pathologic factors was examined using $X^{2}$ analysis. The correlation between APE1 and VEGF expression and MVD was examined using spearman rank correlation analysis. Survival curves were plotted using the Kaplan-Meier method, and the differences between the survival curves were assessed using the log-rank test. Cox regression model was used for analyzing the multivariable factors with DFS of patients. Comparison between the treatment groups and the control group was performed by one-way analysis of variance (ANOVA) test or two-way ANOVA test. $P$ values were two sided; $p$ value $<0.05$ were considered as statistically significant.

\section{Results}

\section{APEI and VEGF expressions in NSCLC pa- tients}

Immunohistochemical assays were performed to investigate the expressions of APE1 in 136 NSCLC tissues and 25 normal lung tissues. In normal lung tissues, the positive staining of APE1 mainly located in the nucleus (Fig.1A). But in NSCLC tissues, APE1 staining located not only in the nucleus, but also in the cytoplasm. As shown in Table 1, 77.94\% (106/136) NSCLC tissues showed high APE1 expression (Fig.1B), and the remaining showed low APE1 expression (Fig.1C). Expressions of VEGF and $\mathrm{CD}_{34}$ were also investigated in NSCLC tissues. VEGF staining mainly located in the cytoplasm, and $66.18 \%$ (90/136) NSCLC tissues showed high VEGF expression (Fig.1D). $\mathrm{CD}_{34}$ staining mainly located in the cytoplasm and membrane of vascular endothelial cells in tumor stroma (Fig.1E). The results showed that the expression of APE1 was not associated with gender, age, histological type, pathological differentiation grade, tumor size and lymphatic nodal status $(\mathrm{P}>0.05)$. The expressions of VEGF and MVD were associated with tumor size and lymphatic nodal status $(\mathrm{P}<0.05)$, and not associated with gender, age, histological type, pathological grade $(\mathrm{P}>0.05)$.

As shown in Table 2, the expressions of APE1 and VEGF were associated with MVD, respectively. In addition, the expression of APE1 showed significant correlation with VEGF and MVD and the rank correlation coefficients were 0.369 and 0.387 , respectively $(\mathrm{P}<0.01)$.

Table 2. The correlation of MVD with APEI and VEGF protein expressions in NSCLC.

\begin{tabular}{lll}
\hline Groups & MVD $($ Mean \pm SD $)$ & P value \\
\hline APE1 & & \\
High expression & $31.08 \pm 6.57$ & $\mathrm{P}=0.002$ \\
Low expression & $26.70 \pm 7.01$ & \\
VEGF & & \\
High expression & $31.93 \pm 6.65$ & $\mathrm{P}=0.000$ \\
Low expression & $26.57 \pm 5.97$ & \\
\hline
\end{tabular}

\section{Relationship between APEI expression and disease free survival (DFS)}

DFS time was accounted from the day of surgery until recurrence or metastasis. The data of the patients without recurrence or metastasis until June 2011 were censored. Kaplan-Meier survival curves and the log-rank test were used to analyze univariate distributions for DFS. Results showed that the 1-, 3- and 5 -year DFS rates were $65.4 \%, 44.6 \%$ and $42.3 \%$, respectively. Figure 2 shows that APE1 higher expression levels had a significantly shorter DFS time compared with APE1 lower expression group, and VEGF high expression is associated with reduced survival. Moreover, the multivariate analysis by COX regression model showed that tumor size, lymphatic nodal status and VEGF expression level were the important independent prognosis factors, which indicated that APE1 expression level may not be an independent prognostic factor in NSCLC. 


\section{lonizing radiation induces expression of APE I and VEGF on A549 cells}

To determine the effect of ionizing radiation on APE1 expression level, western blot analysis was performed on A549 cells treated with various doses of X-ray. As shown in Figs.3A and B, APE1 was strongly expressed and irradiation induced a dose-dependent increase in APE1 protein expression in A549 cells. VEGF is a secreted protein, the upregulation of which is likely to be followed by a rapid increase in export of VEGF out of the cell. Therefore, we performed RT-PCR to examine the VEGF mRNA levels and ELISA to detect VEGF protein level in the A549 culture supernatant. Figs.3C and D show that a dose-dependent increase in VEGF mRNA expression was observed after treatment with increasing doses of irradiation in A549 cells. Moreover, VEGF protein expression was also induced by irradiation in a dose-dependent manner in the A549 culture super- natant (Fig.3E)

\section{Ad5/F35-APE I siRNA inhibits radia- tion-induced APEI expression in A549 cells}

To examine the impact of adenovirus infection on A549 cells, APE1 protein expression was determined by western blot after treatment with Ad5/F35-EGFP or Ad5/F35-APE1 siRNA. As Figs.4A and B shown, Ad5/F35-APE1 siRNA significantly inhibited APE1 expression, whereas the APE1 expression in the Ad5/F35-EGFP group was not changed compared with no treatment control group. Therefore, Ad5/F35-EGFP was used as control for following experiments. We then analyzed the APE1 expression following combination of Ad5/F35-APE1 siRNA and irradiation, and found that irradiation-induced APE1 expression was significantly inhibited by Ad5/F35-APE1 siRNA pretreatment (Figs.4C and D).
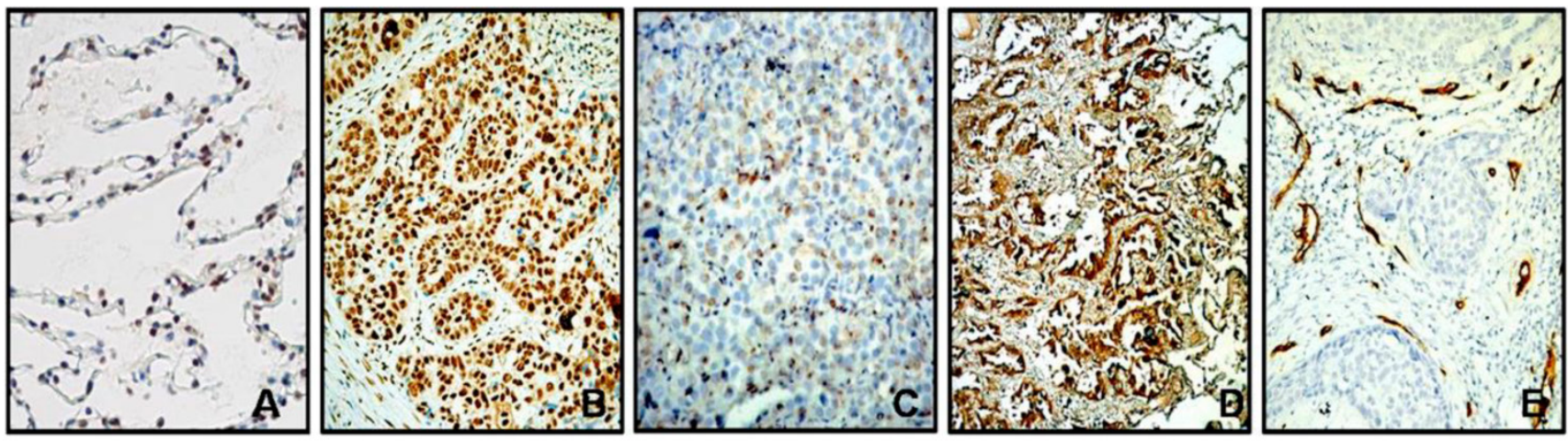

Figure I. Immunohistochemical staining for APEI, VEGF and CD34. (A) Expression of APEI in normal lung tissues; (B) High expression of APEI in NSCLC tissues; (C) Low expression of APEI in NSCLC tissues; (D) High expression of VEGF in NSCLC tissues; (E) High expression of CD ${ }_{34}$ in NSCLC tissues.
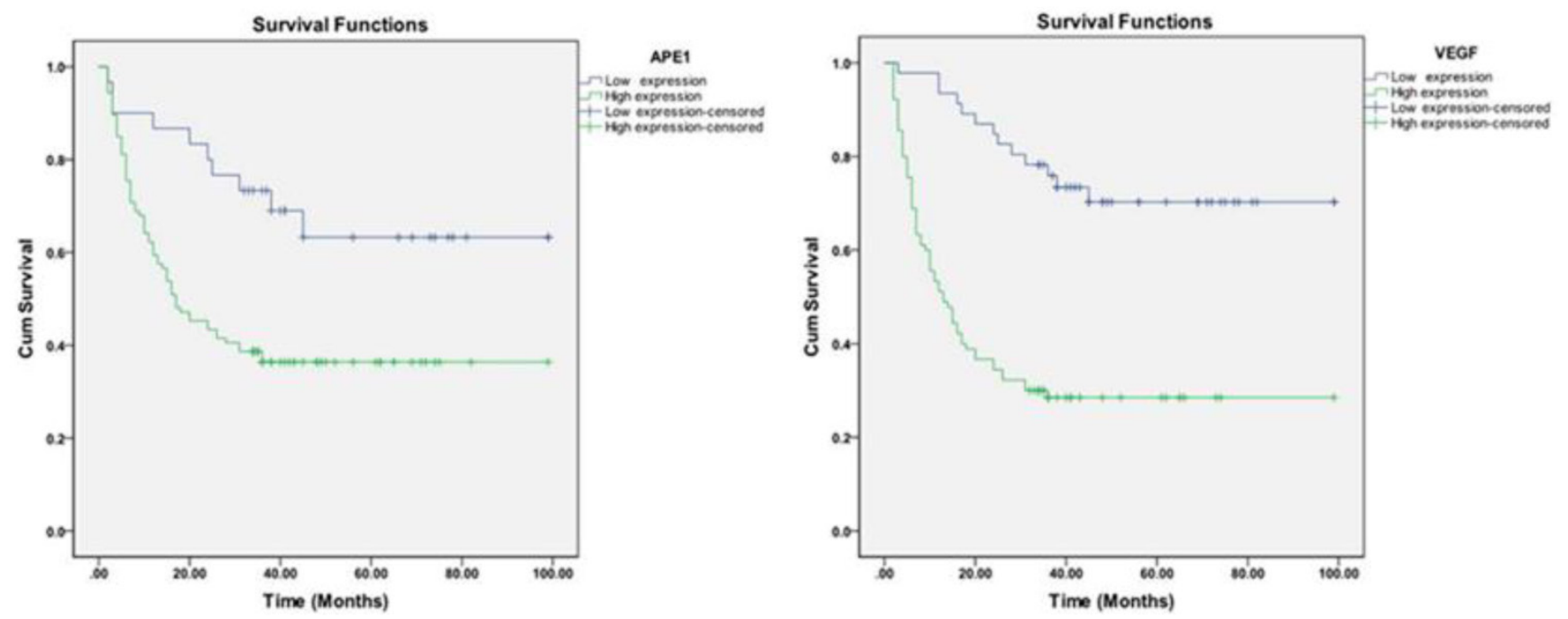

Figure 2. Kaplan-Meier analysis of the effect of APEI and VEGF levels on survival. 

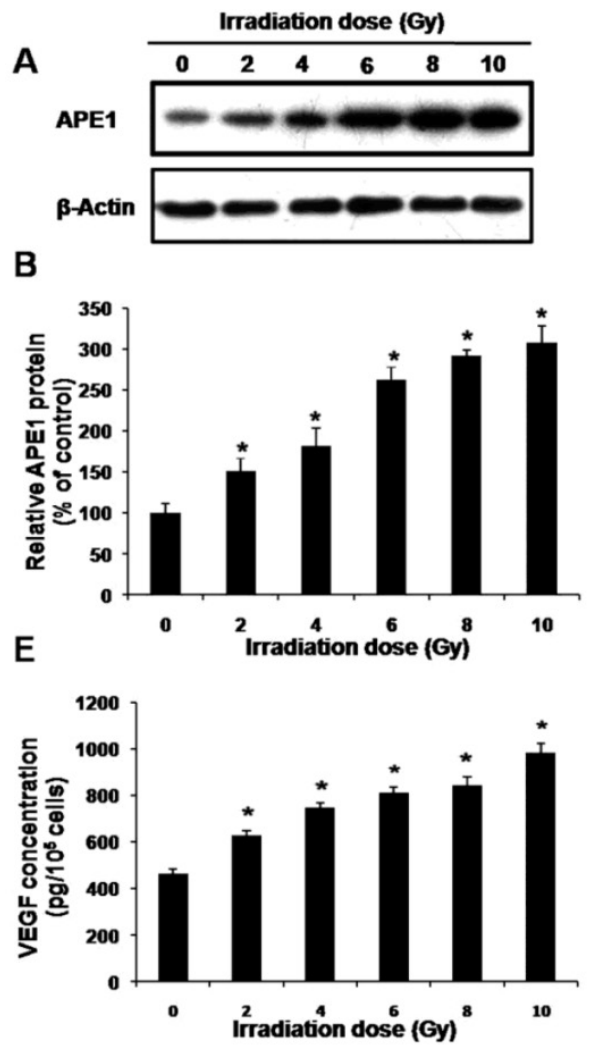

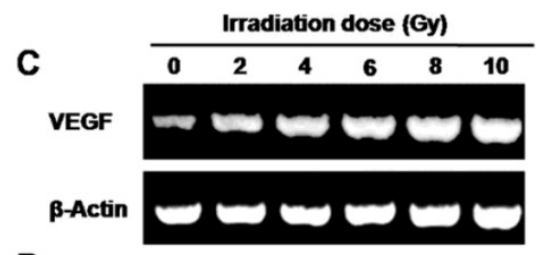

D

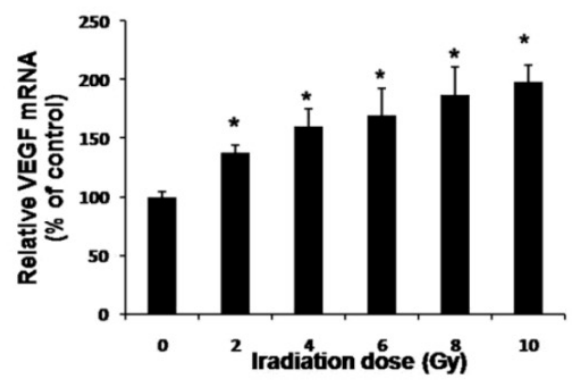

Figure 3. Effects of irradiation on expressions of APEI and VEGF. A549 cells were treated with different doses of X-ray irradiation. (A) Samples were collected at $48 \mathrm{~h}$ post-radiation. Western blot of cell lysates was done with APEI monoclonal antibody and reprobed with $\beta$-actin antibody as a loading control. (B) Normalized APEI protein levels after adjusting for loading. ${ }^{*} \mathrm{p}<0.05 \mathrm{vs}$. control. (C) Samples were collected at $24 \mathrm{~h}$ post-radiation. VEGF mRNA levels were measured by RT-PCR. (D) Normalized VEGF mRNA levels after adjusting for loading. ${ }^{*} \mathrm{p}<0.05$ vs. control. (E) Samples were collected at $48 \mathrm{~h}$ post-radiation, and then VEGF protein levels in the culture supernatant were determined by ELISA.

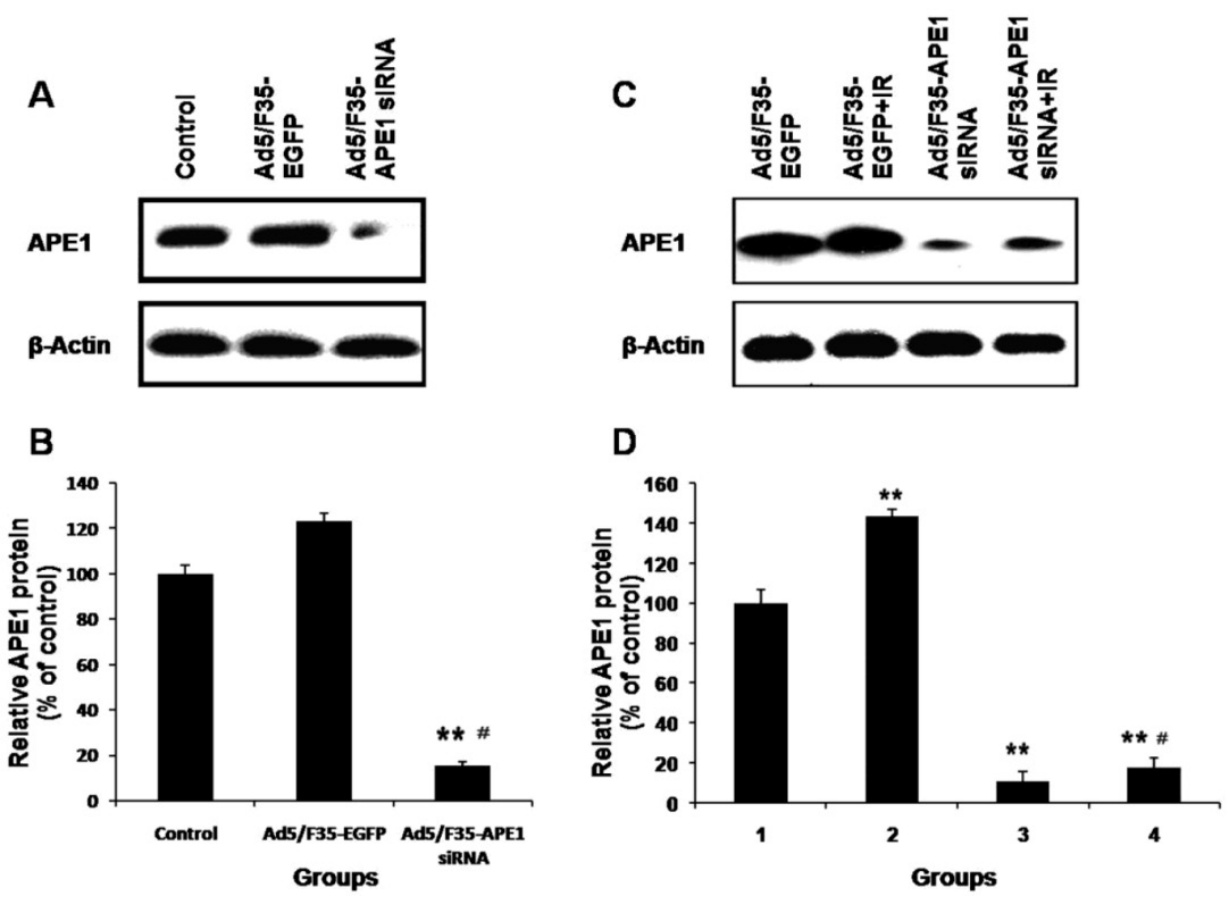

Figure 4. Effects of Ad5/F35-APEI siRNA on expression of APEI. (A) A549 cells were treated with Ad5/F35-APEI siRNA or Ad5/F35-EGFP, and then APEI protein expression was determined at $48 \mathrm{~h}$ post-infection by Western blot and reprobed by $\beta$-actin. (B) Normalized APEI protein levels after adjusting for loading. ${ }^{*} \mathrm{p}<0.01$ vs. Control; ${ }^{*}<0.01$ vs. Ad5/F35-EGFP. (C) After $48 \mathrm{~h}$ post-infection, A549 cells were then irradiated with $4 \mathrm{~Gy}$ of $X$-ray, and then cells were collected at $48 \mathrm{~h}$ post-radiation. Western blot was done with APEI monoclonal antibody and reprobed with $\beta$-actin antibody as a loading control. (D) Normalized APEI protein levels after adjusting for loading. Lane I, Ad5/F35-EGFP; lane 2, Ad5/F35-EGFP+IR; lane 3, Ad5/F35-APEI siRNA; lane 4, Ad5/F35-APEI siRNA+IR. ${ }^{*}{ }^{*}<0.01$ vs. Ad5/F35-EGFP; ${ }^{*} \mathrm{p}<0.01$ vs. Ad5/F35-EGFP+IR. 


\section{Ad5/F35-APEI siRNA inhibits radia- tion-induced VEGF expression}

To investigate the role of APE1 on VEGF mRNA expression level after irradiation, we analyzed the mRNA expression of VEGF in Ad5/F35-APE1 siRNA and irradiation alone group, and combined with Ad5/F35-APE1 siRNA and irradiation group. As shown in Figs.5A and B, the VEGF mRNA expression levels of A549 and HUVECs cells increased after irradiation treatment, and Ad5/F35-APE1 siRNA attenuated the radiation-induced VEGF mRNA expression. There was a dose-dependent increase in VEGF protein in A549 (Fig.5C) and HUVECs (Fig.5D) culture supernatants post-radiation, and the increased VEGF protein expression level was significantly inhibited by Ad5/F35-APE1 siRNA.
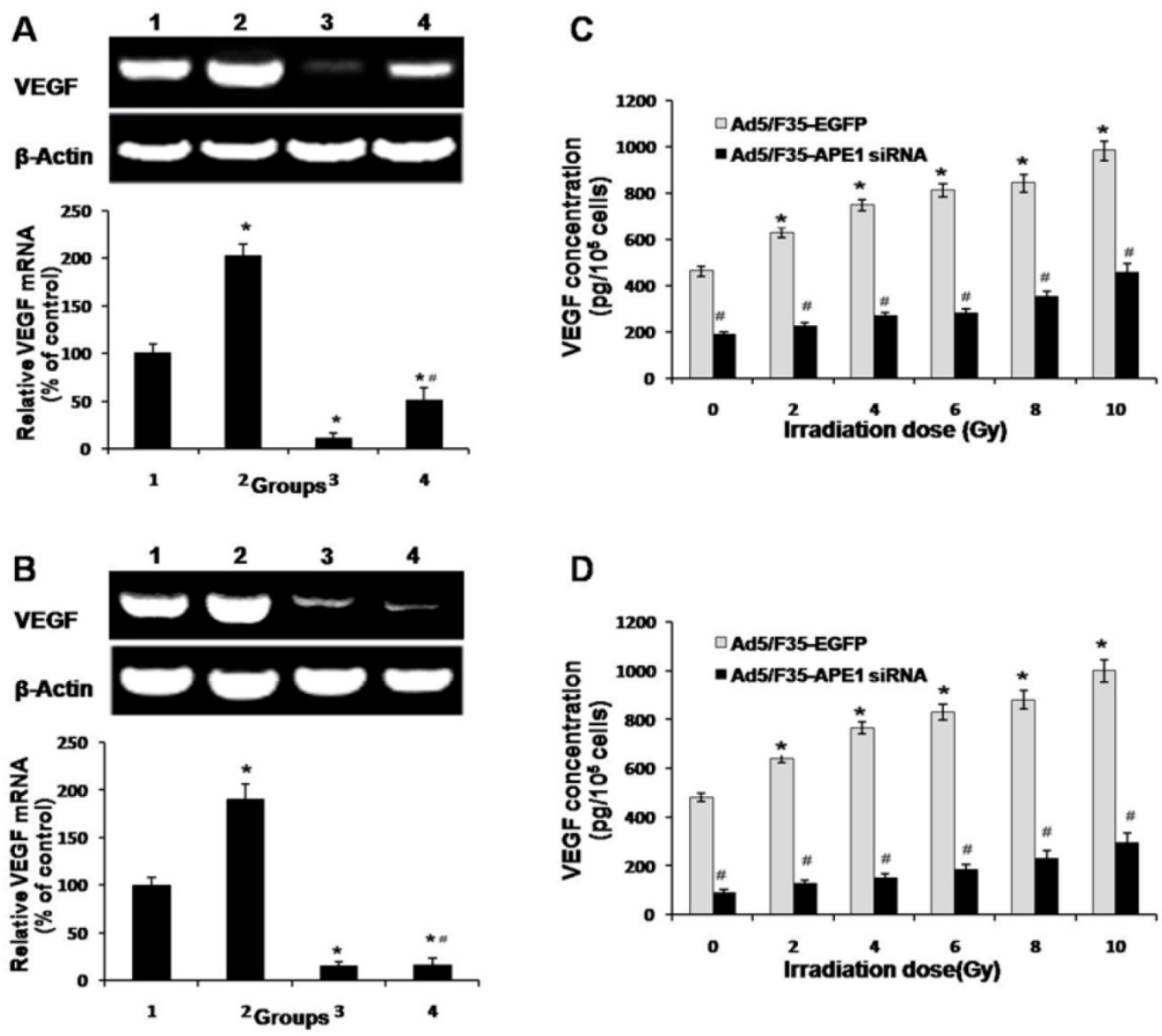

Figure 5. Effects of Ad5/F35-APEI siRNA on expression of VEGF. A549 (A) and HUVECs (B) cells were treated with Ad5/F35-APEI siRNA or Ad5/F35-EGFP and then radiated with $4 \mathrm{~Gy}$ X-ray at $48 \mathrm{~h}$ after infection. Samples were collected at $24 \mathrm{~h}$ post-radiation. RT-PCR analysis of total RNA was done with VEGF mRNA primer and reprobed with $\beta$-actin primer as a loading control. Lane I, Ad5/F35-EGFP; lane 2, Ad5/F35-EGFP+IR; lane 3, Ad5/F35-APEI siRNA; lane 4, Ad5/F35-APEI siRNA+IR. *p<0.05 vs. Ad5/F35-EGFP; \# $p<0.01$ vs. Ad5/F35-EGFP+IR. A549 (C) and HUVECs (D) cells were irradiated with different doses of X-ray at $48 \mathrm{~h}$ post-infection. Samples were collected at $48 \mathrm{~h}$ after irradiation. VEGF protein levels in the culture supernatant were determined by ELISA. * $p<0.05$ different doses irradiation vs. non-irradiation; ${ }^{*} p<0.05$ Ad5/F35-APEI siRNA vs. Ad5/F35-EGFP at same dose of X-ray irradiation. 


\section{APEI regulates VEGF expression in A549 cells through HIF-Ia}

APE1 is a multifunctional protein involved in redox regulation and base excision DNA repair. Through reduction of their critical cysteine residues, APE1 enhances the DNA-binding activity of several transcription factors, including HIF-1a, a well-known transcription factor critically involved in the cellular response to oxidative stress[19]. As VEGF is one of the HIF-1a target genes[31, 32], we hypothesized that APE1 regulated VEGF expression in A549 cells through HIF-1a. To dissect the underlying mechanism, we first determined the potential effects of HIF-1a on VEGF expression. As shown in Fig.6A, the over-expression of HIF-1a in A549 tumor cells by transfection of HIF-1a expressing vector caused the increase of VEGF expression (Fig.6A). Conversely, knockdown of HIF-1a in A549 cells using HIF-1a siRNA decreased the production of VEGF (Fig.6B).
Interestingly, we found that silencing of APE1 by Ad5/F35-APE1 siRNA in A549 cells resulted in a significant reduction of VEGF level when the HIF-1a protein expression remains at the same level (Fig.6C). Then, we further elucidated the effects of Ad5/F35-APE1 siRNA and/or irradiation on transcriptional activation of HIF-1a by EMSA, and found that the DNA-binding activity of HIF-1a was induced by irradiation and the radiation-induced activation of HIF-1a was significantly inhibited by Ad5/F35-APE1 siRNA (Fig.6D). More importantly, there was no significant difference in HIF-1a protein level in Ad5/F35-APE1 siRNA and/or irradiation groups; while the radiation-induced VEGF expression was attenuated by Ad5/F35-APE1 siRNA (Fig.6E). Collectively, these data suggested that APE1 regulates VEGF expression through enhancing the DNA-binding activity of HIF-1a in A549 tumor cells.

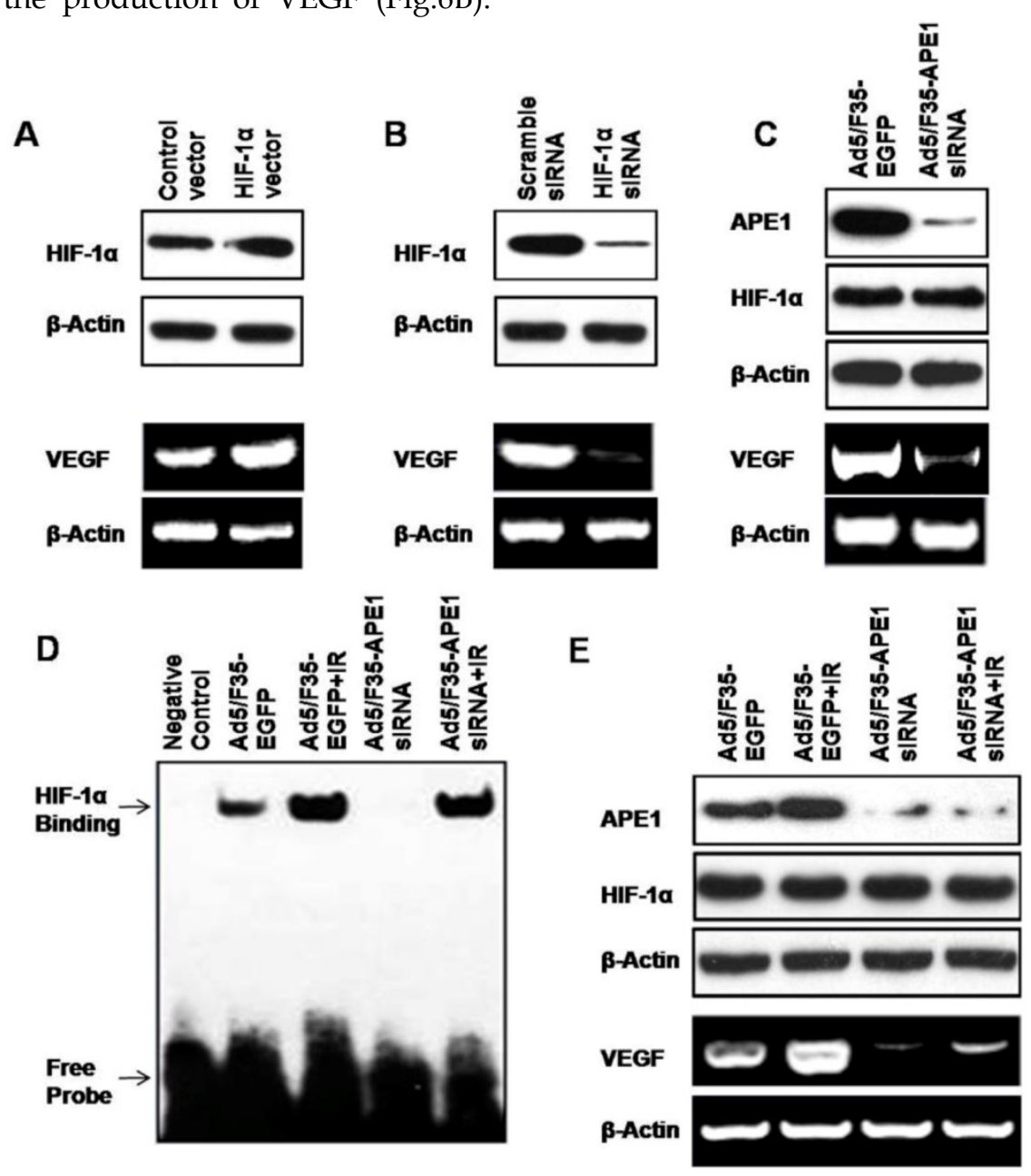

Figure 6. APEI regulates VEGF expression through HIF-I $\alpha$. HIF- I a vector (A) or siRNA (B) was transfected into A549 cells. $48 \mathrm{~h}$ later, the cells were used for HIF-I $\alpha$ analysis by Western blot and VEGF analysis by RT-PCR. (C) Ad5/F35-APEI siRNA was transfected into A549 cells. $48 \mathrm{~h}$ later, the cells were used for APEI and HIF-I $\alpha$ analysis by Western blot and VEGF analysis by RT-PCR. (D and E) A549 cells were infected with Ad5/F35-APEI siRNA or Ad5/F35-EGFP and then radiated at $48 \mathrm{~h}$ post-infection. Cells were harvested for EMSA $5 \mathrm{~h}$ later (D), and collected for APEI and HIF-I $\alpha$ analysis by Western blot and VEGF analysis by RT-PCR at $48 \mathrm{~h}$ post-radiation (E). 


\section{Ad5/F35-APEI siRNA inhibits radia- tion-induced HUVECs immigration and capil- lary-like structure formation in vitro}

To determine the effect of Ad5/F35-APE1 siRNA on endothelial cells immigration induced by irradiation in vitro, we analyzed the immigration of HUVECs using the Transwell assays. As shown in Figs.7A and $B$, the number of migrated HUVECs significantly decreased after infection with Ad5/F35-APE1 siRNA in A549 cells, compared with Ad5/F35-EGFP infection. An obvious increase in migrated HUVECs was observed in A549 irradiation group (Figs.7A and B), possibly promoting metastasis. Then, we analyzed the migration of HUVECs following combined treatment, and found that irradiation-induced HUVECs migra- tion was almost completely inhibited by the pretreatment of A549 cells with Ad5/F35-APE1 siRNA (Figs.7A and B).

To further determine the effect of Ad5/F35-APE1 siRNA on angiogenesis, we examined how Ad5/F35-APE1 siRNA regulates capillary-like structures formation of HUVECs induced by irradiation in vitro. As shown in Fig.7C, conditioned medium from irradiated A549 cells increased HUVECs capillary-like structure formation compared to control non-irradiated conditioned medium, moreover, Ad5/F35-APE1 siRNA decreased the HUVECs capillary-like structures formation induced by ionizing radiation in vitro.
A

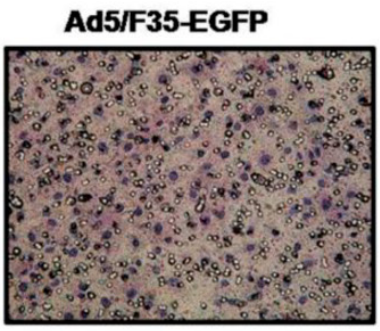

Ad5/F35-APE1 SIRNA

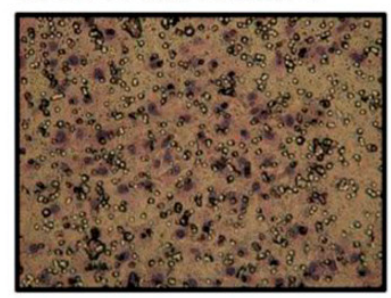

Ad5/F35-EGFP+IR

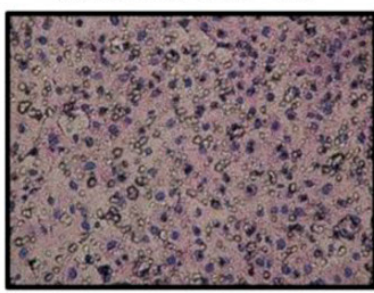

Ad5/F35-APE1 SIRNA+IR

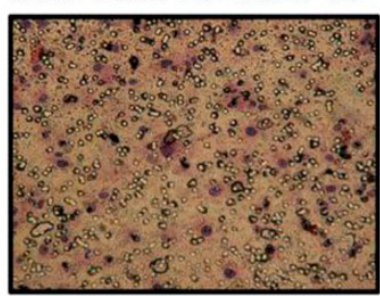

C

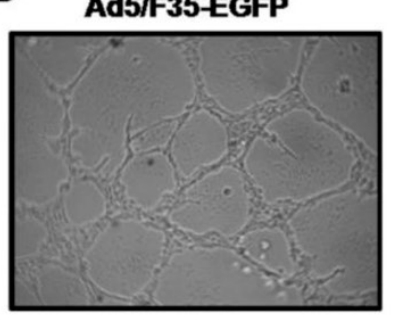

Ad5/F35-APE1 SiRNA

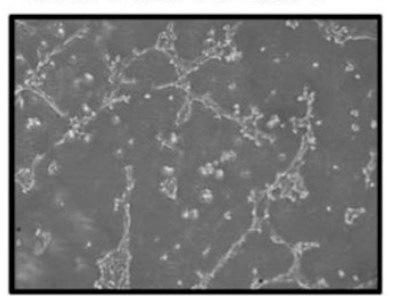

Ad5/F35-EGFP+IR

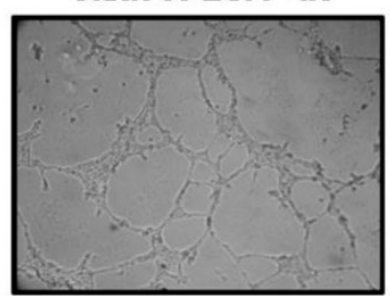

Ad5/F35-APE1 SIRNA+IR

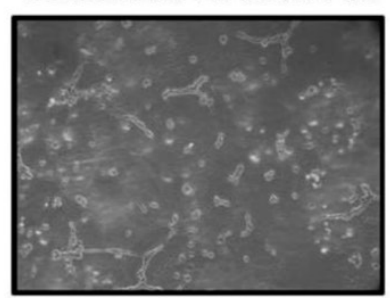

B

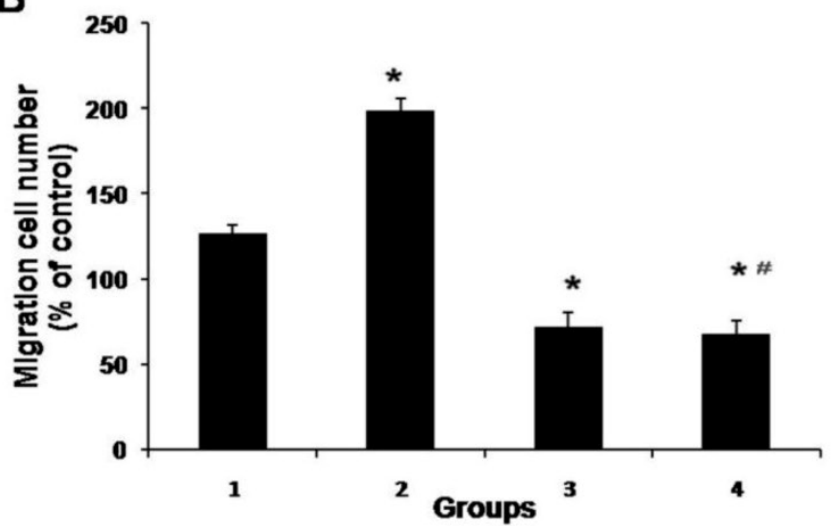

Figure 7. Ad5/F35-APEI siRNA inhibits irradiation-induced migration and capillary-like structure formation of endothelial cells. (A) In vitro migration of endothelial cells was detected using a transwell chamber model (magnification, $\times 200$ ). Irradiation-induced HUVECs migration was inhibited by Ad5/F35-APEI siRNA infection in A549 cells. (B) Each data point represents the mean \pm SD of three independent determinations. Lane I, Ad5/F35-EGFP; lane 2, Ad5/F35-EGFP+IR; lane 3, Ad5/F35-APEI siRNA; lane 4, Ad5/F35-APEI siRNA+IR. " $\mathrm{p}<0.01$ vs. Ad5/F35-EGFP; ${ }^{\#}<<0.01$ vs. Ad5/F35-EGFP+IR. (C) Ad5/F35-APEI siRNA inhibited the irradiation-induced capillary-like structure formation in HUVECs. After incubation, endothelial cells were fixed, and tubular structures were photographed (magnification, $\times 100$ ). 


\section{Discussion}

The human APE1 is a ubiquitous and essential multifunctional protein. APE1 is a key enzyme in BER pathway which is responsible for the repair of oxidative and alkylation DNA damage. In addition to its DNA repair functions, APE1 also is a redox regulator to stimulate the DNA binding activity of numerous transcription factors that are involved in cancer promotion and progression, such as Fos, Jun, NF-kB, paired box containing family of genes (PAX), HIF-1a, HIF-1-like factor (HLF), and p53, then to participate in many crucial cellular processes, including the response to oxidative stress, regulation of transcription factors, cell cycle control, and apoptosis[33].

VEGF is known to be a crucial angiogenic factor and play an important role in promoting angiogenesis; meanwhile, HIF-1a is a critical transcriptional factor to promote the VEGF expression. Therefore, it is reasonable to consider that APE1 might be a regulator in angiogenesis. Alteration of APE1 protein level and subcellular localization is often observed in lung cancer and many other human tumors, which is associated with response to treatments and prognostic significance[23-25, 34-38]. In this study, we also showed that APE1 protein level was related with DFS in patients with NSCLC, but APE1 was not an independent prognostic factor for DFS by COX regression model. We presumed the reason might be that APE1 expression was significant correlated with VEGF and MVD. Our previous study has demonstrated that pSilence-Ape1 can significantly suppress the expression of VEGF in human osteosarcoma 9901 cells and combined treatment with pSilenceApe1 and recombinant human endostatin showed potent antiangiogenic effects in the transwell chamber invasion assay[22]. In this study, the results show that Ad5/F35-APE1 siRNA efficiently inhibited APE1 protein expression and significantly decreased DNA binding activity of HIF-1 $\alpha$ and suppressed VEGF expression in human lung adenocarcinoma A549 cells. Moreover, the APE1 knockdown of A549 cells inhibited co-cultured endothelial cells immigration and capillary-like structure formation.

Recently, the mechanisms of APE1 regulating HIF-1a have been studied by many researchers. The regulation of HIF-1 activity is primarily determined by the stability of the HIF-1a protein. Over-expression of APE1 can enhance the transcription activity of HIF-1 through redox-dependent stabilization of HIF-1a protein[39]. HIF-1a contains within its C-terminus two transactivation domains, and the hypoxia-inducible activity of both the two domains was enhanced by either SRC-1 or cAMP responsive element binding protein (CBP)/p300 coactivator. APE1 promotes redox-dependent interactions between HIF-1 and transcription coactivators SRC-1 and $\mathrm{CBP} / \mathrm{p} 300$. All three proteins, CBP, SRC-1, and APE1, are important components of the hypoxia signaling pathway and have a common function in regulation of HIF-1a function in hypoxic cells. They form a multiprotein complex binding to adjacent and sometimes non-adjacent sequences in the hypoxic response element of HIF-1a[40]. One study has showed in both pancreatic and prostate carcinoma cell lines the transcription complex comprising signal transducer and activators of transcription 3 (STAT3), HIF-1a, $\mathrm{CBP} / \mathrm{p} 300$ and APE1 binding to the VEGF promoter is required for maximum transcription of VEGF following hypoxia[21]. Another study has also suggested that APE1 is a critical component of the hypoxia-inducible transcriptional complex forming on the VEGF gene's hypoxic response element and that the presence of APE1 in the complex is required for the apparent high affinity association between HIF-1 and its DNA recognition sequence[20].

Radiotherapy is an important approach of local and regional therapy for many types of cancer, but many studies have reported radiotherapy can stimulate multiple signal transduction pathways simultaneously and alter the expression of proangiogenic molecules in cancer and host cells to induce angiogenesis, thereby diminishing treatment response by inducing tumor recurrence or metastasis. The irradiation-induced increase of HIF-1-regulated cytokines enhances endothelial cell radioresistance, which may be major determinants of tumor radiosensitivity[16]. Radiotherapy can modulate VEGF expression through multiple mitogen activated protein kinase (MAPK) dependent pathways[14]. Low-dose irradiation promotes tissue revascularization through VEGF release from mast cells and MMP-9-mediated progenitor cell mobilization[41]. Radiotherapy induces angiogenesis through the upregulation of the nitric oxide pathway in the endothelial cells[42]. Likewise, radiotherapy can induce VEGF expression in lung cancer. The lung squamous cell carcinoma RERF-LC-AI cells irradiated with single doses of 15 Gy either X-rays or carbon ions have showed significantly increased VEGF mRNA expression up to 2.81-fold of control at 16 24 h after irradiation, and a significant increase has also been observed in VEGF protein levels in culture supernatant at $24 \mathrm{~h}$ after irradiation with 50 and $90 \mathrm{keV} /$ microm carbon ions. The VEGF mRNA and protein induction has showed dose-dependent and independence on LET[13, 43]. Another study has also reported that VEGF expression is induced in Lewis lung carcinomas (LLCs) after 
exposure to ionizing radiation, moreover, treatment of tumor-bearing mice with a neutralizing antibody to VEGF-165 before irradiation is associated with a greater than additive antitumor effect[44]. As APE1 can regulate VEGF through the transcription factors such as HIF-1a, APE1 may play an important role in irradiation-induced angiogenesis, and also may contribute to understand the molecular mechanism of radiation resistance and irradiation-induced cancer invasion and metastasis.

Several researches have revealed that APE1 is showed high expression on NSCLC tumors of radiation-resistant and cisplatin-resistant tumors, which suggests that APE1 is associated with response to chemotherapy or radiotherapy and chemoradiotherapy in NSCLC patients[23-25]. Our previous work has showed ionizing radiation can enhance APE1 expression in the human lung adenocarcinoma A549 cells[25], and targeted inhibition of APE1 can enhance the effect of cisplatin and radiation[23, 24]. In the present study, we further confirmed that APE1 was strongly expressed and irradiation induced a dose-dependent increase in APE1 protein expression in A549 cells, and Ad5/F35-APE1 siRNA could significantly decrease DNA binding activity of HIF-1a and suppress the expression of VEGF in irradiated A549 cells. Therefore, knockdown of APE1 not only significantly suppressed VEGF expression but also suppressed VEGF expression induced by ionizing radiation in A549 cells. Moreover, Ad5/F35-APE1 siRNA was shown to inhibit co-cultured endothelial cells immigration by transwell chamber co-culture system and capillary-like structure formation induced by X-ray irradiation. Previous other study has also demonstrated that simultaneous downregulation of NF-KB and HIF-1a in PC-3 prostate cancer cells by inhibition of APE1 could decrease both cell survival and VEGF-mediated angiogenesis[45]. Our study implicates the redox regulatory function of APE1, but cannot exclude a role for one of the other activities of APE1. Thus, to further explore the role of the APE1 redox function during radiation-induced angiogenesis in lung cancer cells, it is like that selective inhibitor of the APE1 redox function like APX3330 should be used, as previously described by Jiang et al[46]. However, our findings suggest that APE1 may be an important therapeutic target in angiogenesis induced by ionizing radiation. One strategy for tumor gene therapy is to inhibit expression of APE1 to decrease angiogenesis induced by ionizing radiation to enhance the radiotherapy response, and effectively eliminate metastasis. Therefore, targeting of APE1 holds great potential clinical significance in combination with radiotherapy for NSCLC.

\section{Acknowledgements}

The work was supported by the National Natural Science Foundation of China (No. 30901747).

\section{Competing Interests}

The authors have declared that no competing interest exists.

\section{References}

1. Jemal A, Bray F, Center MM, Ferlay J, Ward E, Forman D. Global cancer statistics. CA Cancer J Clin. 2011; 61: 69-90.

2. Kong FM, Ten Haken RK, Schipper MJ, Sullivan MA, Chen M, Lopez C, et al. High-dose radiation improved local tumor control and overall survival in patients with inoperable/unresectable non-small-cell lung cancer: long-term results of a radiation dose escalation study. Int J Radiat Oncol Biol Phys. 2005; 63: 324-33.

3. Bradley JD, Moughan J, Graham MV, Byhardt R, Govindan R, Fowler J, et al. A Phase I/II Radiation Dose Escalation Study with Concurrent Chemotherapy for Patients with Inoperable Stages I-III Non-Small Cell Lung Cancer: The Phase I Results of RTOG 0117. Int J Radiat Oncol Biol Phys. 2010; 77: 367-72.

4. Madani I, De Neve W, Mareel M. Does ionizing radiation stimulate cancer invasion and metastasis. Bull Cancer. 2008; 95: 292-300.

5. Von Essen CF. Radiation enhancement of metastasis: a review. Clin Exp Metastasis. 1991; 9: 77-104.

6. Rak JW, St Croix BD, Kerbel RS. Consequences of angiogenesis for tumor progression, metastasis and cancer therapy. Anticancer Drugs. 1995; 6: 3-18.

7. Folkman J, Camphausen K. What does radiotherapy do to endothelial cells? Science. 2001; 293: 227-8.

8. Koukourakis MI. Tumour angiogenesis and response to radiotherapy. Anticancer Res. 2001; 21: 4285-300.

9. Folkman J. Role of angiogenesis in tumor growth and metastasis. Semin Oncol. 2002; 29: 15-8.

10. Semenza GL. Intratumoral hypoxia, radiation resistance, and HIF-1. Cancer Cell. 2004; 5: 405-6.

11. Vala IS, Martins LR, Imaizumi N, Nunes RJ, Rino J, Kuonen F, et al. Low doses of ionizing radiation promote tumor growth and metastasis by enhancing angiogenesis. PloS One. 2010; 5: e11222.

12. Kargiotis O, Geka A, Rao JS, Kyritsis AP. Effects of irradiation on tumor cell survival, invasion and angiogenesis. J Neurooncol. 2010; 100: 323-38.

13. Ando S, Nojima K, Majima H, Ishihara H, Suzuki M, Furusawa $Y$, et al. Evidence for mRNA expression of vascular endothelial growth factor by X-ray irradiation in a lung squamous carcinoma cell line. Cancer Lett. 1998; 132: 75-80.

14. Park JS, Qiao L, Su ZZ, Hinman D, Willoughby K, McKinstry R, et al. Ionizing radiation modulates vascular endothelial growth factor (VEGF) expression through multiple mitogen activated protein kinase dependent pathways. Oncogene. 2001; 20: 3266-80.

15. Lund EL, Hog A, Olsen MWB, Hansen LT, Engelholm SA, Kristjansen PEG. Differential regulation of VEGF, HIF1alpha and angiopoietin-1, -2 and -4 by hypoxia and ionizing radiation in human glioblastoma. Int $\mathrm{J}$ Cancer. 2004; 108: 833-8.

16. Moeller BJ, Cao Y, Li CY, Dewhirst MW. Radiation activates HIF-1 to regulate vascular radiosensitivity in tumors: role of reoxygenation, free radicals, and stress granules. Cancer Cell. 2004; 5: 429-41.

17. Kaliski A, Maggiorella L, Cengel KA, Mathe D, Rouffiac V, Opolon P, et al. Angiogenesis and tumor growth inhibition by a matrix metalloproteinase inhibitor targeting radiation-induced invasion. Mol Cancer Ther. 2005; 4: 1717-28.

18. Fleck O, Nielsen O. DNA repair. J Cell Sci. 2004; 117: 515-7.

19. Bhakat KK, Mantha AK, Mitra S. Transcriptional regulatory functions of mammalian AP-endonuclease (APE1/Ref-1), an essential multifunctional protein. Antioxid Redox Signal. 2009; 11: 621-38.

20. Ziel KA, Campbell CC, Wilson GL, Gillespie MN. Ref-1/Ape is critical for formation of the hypoxia-inducible transcriptional complex on the hypoxic response element of the rat pulmonary artery endothelial cell VEGF gene. FASEB J. 2004; 18: 986-8.

21. Gray MJ, Zhang J, Ellis LM, Semenza GL, Evans DB, Watowich SS, et al. HIF-1a, STAT3, CBP/p300 and Ref-1/APE are components of a transcriptional complex that regulates Src-dependent hypoxia-induced ex- 
pression of VEGF in pancreatic and prostate carcinomas. Oncogene. 2005; $24: 3110-20$.

22. Wang D, Zhong ZY, Li MX, Xiang DB, Li ZP. Vector-based Ape1 small interfering RNA enhances the sensitivity of human osteosarcoma cells to endostatin in vivo. Cancer Sci. 2007; 98: 1993-2001.

23. Wang D, Xiang DB, Yang X, Chen LS, Li MX, Zhong ZY, et al. APE1 overexpression is associated with cisplatin resistance in non-small cell lung cancer and targeted inhibition of APE1 enhances the activity of cisplatin in A549 cells. Lung Cancer. 2009; 66: 298-304.

24. Singh-Gupta V, Joiner MC, Runyan L, Yunker CK, Sarkar FH, Miller S, et al. Soy isoflavones augment radiation effect by inhibiting APE1/Ref-1 DNA repair activity in non-small cell lung cancer. J Thorac Oncol. 2011; 6: 688-98.

25. Zhang ZM, Yang XQ, Wang D, Wang G, Yang ZZ, Qing Y, et al. Nm23-H1 protein binds to APE1 at AP sites and stimulates AP endonuclease activity following ionizing radiation of the human lung cancer A549 cells. Cell Biochem Biophys. 2011; 61: 561-72.

26. Edge SB, Byrd DR, Compton CC, Fritz AG, Greene FL, Trotti A. AJCC cancer staging manual. Springer, New York. 2010;: 113-20.

27. Xiang DB, Chen ZT, Wang D, Li MX, Xie JY, Zhang YS, et al. Chimeric adenoviral vector Ad5/F35-mediated APE1 siRNA enhances sensitivity of human colorectal cancer cells to radiotherapy in vitro and in vivo. Cancer Gene Ther. 2008; 15: 625-35.

28. Patel N, Kalra VK. Placenta growth factor-induced early growth response 1 (Egr-1) regulates hypoxia-inducible factor-1alpha (HIF-1alpha) in endothelial cells. J Biol Chem. 2010; 285: 20570-9.

29. Hashimoto G, Inoki I, Fujii Y, Aoki T, Ikeda E, Okada Y. Matrix metalloproteinases cleave connective tissue growth factor and reactivate angiogenic activity of vascular endothelial growth factor 165 . J Biol Chem. 2002; 277: 36288-95

30. Lai KB, Sanderson JE, Yu CM. The regulatory effect of norepinephrine on connective tissue growth factor (CTGF) and vascular endothelial growth factor (VEGF) expression in cultured cardiac fibroblasts. Int J Cardiol. 2013; 163: 183-9.

31. Forsythe JA, Jiang BH, Iyer NV, Agani F, Leung SW, Koos RD, et al. Activation of vascular endothelial growth factor gene transcription by hypoxia-inducible factor 1. Mol Cell Biol. 1996; 16: 4604-13.

32. Maxwell PH, Ratcliffe PJ. Oxygen sensors and angiogenesis. Semin Cell Dev Biol. 2002; 13: 29-37.

33. Evans AR, Limp-Foster M, Kelley MR. Going APE over ref-1. Mutat Res. 2000; 461: 83-108

34. Puglisi F, Aprile G, Minisini AM, Barbone F, Cataldi P, Tell G, et al. Prognostic significance of Ape1/ref-1 subcellular localization in non-small cell lung carcinomas. Anticancer Res. 2001; 21: 4041-9.

35. Puglisi F, Barbone F, Tell G, Aprile G, Pertoldi B, Raiti C, et al. Prognostic role of Ape/Ref-1 subcellular expression in stage I-III breast carcinomas. Oncol Rep. 2002; 9: 11-7.

36. Robertson KA, Bullock HA, Xu Y, Tritt R, Zimmerman E, Ulbright TM, et al. Altered expression of Ape1/ref-1 in germ cell tumors and overexpression in NT2 cells confers resistance to bleomycin and radiation. Cancer Res. 2001; 61: 2220-5.

37. Koukourakis MI, Giatromanolaki A, Kakolyris S, Sivridis E, Georgoulias V, Funtzilas G, et al. Nuclear expression of human apurinic/apyrimidinic endonuclease (HAP1/Ref-1) in head-and-neck cancer is associated with resistance to chemoradiotherapy and poor outcome. Int J Radiat Oncol Biol Phys. 2001; 50: 27-36.

38. Wang D, Luo M, Kelley MR. Human apurinic endonuclease 1 (APE1) expression and prognostic significance in osteosarcoma: enhanced sensitivity of osteosarcoma to DNA damaging agents using silencing RNA APE1 expression inhibition. Mol Cancer Ther. 2004; 3: 679-86.

39. Huang LE, Arany Z, Livingston DM, Bunn HF. Activation of hypoxia-inducible transcription factor depends primarily upon redox-sensitive stabilization of its alpha subunit. J Biol Chem. 1996; 271: 32253-9.

40. Carrero P, Okamoto K, Coumailleau P, O'Brien S, Tanaka H, Poellinger L. Redox-regulated recruitment of the transcriptional coactivators CREB-binding protein and SRC-1 to hypoxia-inducible factor 1alpha. Mol Cell Biol. 2000; 20: 402-15.

41. Heissig B, Rafii S, Akiyama H, Ohki Y, Sato Y, Rafael T, et al. Low-dose irradiation promotes tissue revascularization through VEGF release from mast cells and MMP-9-mediated progenitor cell mobilization. J Exp Med. 2005; 202: 739-50.

42. Sonveaux P, Brouet A, Havaux X, Gregoire V, Dessy C, Balligand JL, et al. Irradiation-induced angiogenesis through the up-regulation of the nitric oxide pathway implications for tumor radiotherapy. Cancer Res. 2003; 63: 1012-9.

43. Ando S, Nojima K, Ishihara H, Suzuki M, Ando M, Majima H, et al. Induction by carbon-ion irradiation of the expression of vascular endo- thelial growth factor in lung carcinoma cells. Int J Radiat Biol. 2000; 76: 1121-7.

44. Gorski DH, Beckett MA, Jaskowiak NT, Calvin DP, Mauceri HJ, Salloum $\mathrm{RM}$, et al. Blockade of the vascular endothelial growth factor stress response increases the antitumor effects of ionizing radiation. Cancer Res. 1999; 59: 3374-8.

45. Singh GV, Zhang H, Banerjee S, Kong D, Raffoul JJ, Sarkar FH, et al. Radiation-induced HIF-1 alpha cell survival pathway is inhibited by soy isoflavones in prostate cancer cells. Int J Cancer. 2009; 124: 1675-84.

46. Jiang A, Gao H, Kelley MR, Qiao X. Inhibition of APE1/Ref-1 redox activity with APX3330 blocks retinal angiogenesis in vitro and in vivo. Vision Res. 2011; 51: 93-100. 